\title{
The Contributions of the Hong Kong International Arbitration Centre to Effective International Dispute Resolution
}

\author{
Matthew Gearing and Joe Liu*
}

\begin{abstract}
This chapter traces the evolution of the Hong Kong International Arbitration Centre (HKIAC)from 1985 when it was established as a regional arbitration center to its present status as one of the world's major international dispute resolution organizations. The chapter focuses on HKIAC's contributions to effective international dispute resolution over that time, including its participation in legislative reforms in and outside of Hong Kong, its global outreach efforts and its promulgation of arbitration rules with trend-setting provisions for increasingly complex disputes. HKIAC's case statistics will be used to identify trends in international dispute resolution and to present HKIAC's experience in international commercial and investment treaty cases involving governments entities or international organizations.

The chapter will then discuss the use of HKIAC for dispute resolution by international organizations. In that respect, real-life examples will be used to examine a number of disputes that were submitted by an international organization to HKIAC for arbitration under a loan agreement or a shareholders agreement. The chapter will also discuss a recent project in which an international organization decided to include an HKIAC dispute resolution clause in its employment agreements after considering other alternatives.

The chapter will conclude by addressing HKIAC's unique position to resolve disputes between Chinese and non-Chinese parties with a particular focus on disputes arising from China's Belt and Road Initiative.
\end{abstract}

\section{Introduction}

The Hong Kong International Arbitration Centre (HKIAC) is a non-profit company limited by guarantee incorporated under Hong Kong law. Since its

\footnotetext{
* Matthew Gearing, Chairperson, HKIAC, matthew.gearing@allenovery.com; Joe Liu, Deputy Secretary-General, HKIAC, joe@hkiac.org.

(C) ASIAN INFRASTRUCTURE INVESTMENT BANK (AIIB), 2019 | DOI:10.1163/9789004407411_005
}

This is an open access chapter distributed under the terms of the CC-BY-NC 4.o License. 
establishment in 1985, HKIAC has evolved from a regional hearing center to one of the world's top four arbitral institutions. ${ }^{1}$ According to Global Arbitration Review (GAR), '[i]f regional arbitration has a home, it is in Asia. More specifically, in Hong Kong ... The HKIAC's success inspired many of others ... Regional arbitration pretty much began with HKIAC. No regional arbitral institution has been running for so long, or with such success.'

Over the past 34 years, HKIAC has played an active role in promoting and implementing best practice of resolving international commercial and investment disputes. In that respect, HKIAC has made notable progress through the promulgation of rules, participation in legislative reforms and collaborations with various interest groups and stakeholders. HKIAC has also applied international best practice in cases submitted to it with recent statistics and projects showing a growing number of government entities and international organizations selecting the Centre as the venue for resolving their disputes. With its ongoing efforts and proven record, HKIAC is set to make greater contributions to international dispute resolution, particularly in the context of the Belt and Road Initiative. ${ }^{3}$

This chapter will begin with an overview of the evolution of HKIAC, followed by a discussion of the impact of the Centre's work and initiatives on the development of international arbitration. HKIAC's recent statistics will then be used to analyze the key trends in international dispute resolution and case studies will be presented to discuss the use of HKIAC for disputes involving international organizations. The chapter will conclude by discussing HKIAC's experience in disputes between Chinese and non-Chinese parties and its anticipated role in China's future outbound investment projects.

HKIAC was established to meet the needs of the legal and business community in Hong Kong by providing facilities and other support services for arbitration hearings in the city.

In the 1980s, the growth of the Asian economy resulted in an increased volume of cross-border transactions. At that time, Hong Kong was emerging as an important financial center in Asia and China was becoming a key trading

1 Queen Mary University of London and White \& Case 2018.

2 Global Arbitration Review, Guide to Regional Arbitration 2018.

3 The Belt \& Road Initiative (BRI) is an extensive outbound investment initiative launched by the Chinese government in 2013 as an official policy to stimulate economic development along an overland 'Silk Road Economic Belt' and a maritime '21st Century Maritime Silk Road'. For further information about BRI, please see section 5 below. 
partner of Hong Kong. International commercial parties in the region preferred to use arbitration to resolve cross-border commercial disputes. However, there was no established arbitration center in the region at the time.

In 1980, the Law Reform Commission of Hong Kong (HKLRC) was constituted to review Hong Kong's laws and to consider reforms necessary to meet the needs of the legal and business community in Hong Kong. H KLRC found that Hong Kong had the potential to develop into a leading center for resolving local and international commercial disputes in Asia, but the city did not have the necessary premises or services to host arbitration hearings.

Prompted by HKLRC's recommendations, the then Attorney General of Hong Kong formed a steering committee to consider the feasibility of establishing an arbitral institution in Hong Kong and the rules the institution should adopt. Upon recommendations by the steering committee, the Hong Kong government agreed to support this initiative by pledging to raise funds to establish an arbitral institution and to provide premises at the old Central Magistracy Building in Hong Kong.

In September 1985, HKIAC was established and began operations. In October 1994, following an increased demand for centralized hearing premises, the Hong Kong government granted HKIAC a lease on favorable terms for premises comprising half of the 38th floor of a prime office building in the Central District, Two Exchange Square. In 2012, HKIAC further expanded into the remainder of the 38th floor with additional hearing facilities. Since 2015, HKIAC's hearing facilities have repeatedly been ranked first worldwide for location, value for money, IT services, and helpfulness of staff. ${ }^{4}$

In May 2013, HKIAC opened its first overseas office in Seoul to promote its services in Korea. In November 2015, H KIAC opened its second overseas office in Shanghai, marking the first time an offshore arbitral institution has set up a formal presence in Mainland China.

Prior to 2008, HKIAC provided administrative and support services only in arbitrations under the UnCITRAL Arbitration Rules (UnCITRAL Rules) 5 or the arbitration legislation of Hong Kong. In September 2008, HKIAC introduced its first Administered Arbitration Rules (HKIAC Rules) and began to administer arbitrations under its own rules. The Rules have subsequently been amended

4 Global Arbitration Review, 'Hearing Centre Survey', 2 January 2019.

5 The Uncitral Rules are a set of procedural rules issued by the United Nations Commission on International Trade Law. Parties may adopt these rules for the conduct of arbitral proceedings arising out of their commercial, investor-State or State-to-State disputes. The rules can be used in ad hoc arbitrations and administered arbitrations. For further information, please see UNCITRAL, Arbitration Rules 1979, 2010, 2013. 
twice, with the second version taking effect on 1 November 2013 and the third and current version coming into force on 1 November 2018.

In addition to arbitration and hearing facilities, HKIAC provides mediation and domain name dispute resolution services. The Centre began to provide mediation services under its mediation rules in 1999 and has been appointed as the body to resolve disputes in respect of various domain names since 2001 .

With its broad range of dispute resolution services and state-of-the-art facilities, based upon HKIAC's internal data collection, approximately 10,000 cases have been handled to date, involving private companies, state-owned enterprises, government bodies and international organizations from more than 40 jurisdictions.

Contributions of H KIAC to the Development of International Arbitration

HKIAC contributes to the development of international arbitration in three key ways. These are the promulgation of procedural rules, participation in legislative reforms, and promotion of best arbitration practice through its outreach program and events.

\subsection{Promulgation of Procedural Rules}

HKIAC is at the forefront of developing procedural rules with the objectives of bringing time efficiency, cost effectiveness and procedural certainty to arbitral processes. Since 1986, H KIAC has promulgated multiple sets of rules. ${ }^{6}$ Its primary and latest set is the 2018 HKIAC Administered Arbitration Rules (2018 Rules), which came into force on 1 November 2018 following a comprehensive rules revision and public consultation process.

The 2018 Rules codify the best-known and unique features of HKIACadministered arbitration into one set of procedures. With those features, the 2018 Rules set the latest standards for international arbitration practice and have a positive impact on the development of international arbitral procedures. The key features of the 2018 Rules are summarized below:

- Choice of method to pay arbitrators' fees: ${ }^{7}$ HKIAC is the first institution to allow parties to agree on how to pay their arbitrators. The 2018 Rules offer two options: payment by hourly rate (capped at HK\$6,500/hour) or based

6 HKIAC, 'Rules \& Practice Notes'.

7 HKIAC, Arbitration Rules 2018, art 10, schs 2 and 3. 
on the amount in dispute, with the former as the default option. Parties can strategically choose the best option to save costs, for example, payment by hourly rate for simple but high-value disputes and payment based on the amount in dispute for complex but low-value disputes.

- Multi-party and multi-contract provisions: HKIAC offers a wide range of procedural mechanisms to streamline proceedings involving multiple parties or multiple contracts. These mechanisms are the joinder of an additional party to an arbitration, ${ }^{8}$ consolidation of multiple arbitrations, ${ }^{9}$ the commencement of a single arbitration under multiple contracts ${ }^{10}$ and concurrent proceedings. ${ }^{11}$ These provisions are known for their flexibility and broad scope of application.

- Emergency Arbitrator Procedure: ${ }^{12}$ A party may seek the appointment of an emergency arbitrator before, concurrent with or after the commencement of an arbitration. Upon receipt of the application and required deposit, HKIAC will seek to appoint an emergency arbitrator within 24 hours. Once the case file is transmitted to the emergency arbitrator, he or she will apply an express test to decide on the application within 14 days for a total fee not exceeding $\mathrm{HK} \$ 200,000$.

- Expedited Procedure: ${ }^{13}$ Since 2008, HKIAC's Expedited Procedure has been widely used by parties to fast track their arbitrations through the appointment of a sole arbitrator (unless all parties agree to three) to decide the dispute based on documents only within six months. Upon a party's request, HKIAC may apply the Expedited Procedure before the arbitral tribunal is constituted where (a) the total amount in dispute does not exceed $\mathrm{HK} \$ 25$ million; (b) all parties so agree; or (c) in cases of exceptional urgency.

- Early Determination Procedure: ${ }^{14}$ The 2018 Rules feature an Early Determination Procedure (EDP) to deal with meritless points of law or fact through a separate process under short but extendable time limits. EDP empowers an arbitral tribunal to determine a point of law or fact that is manifestly without merit or manifestly outside of its jurisdiction, or a point of law or fact, assuming it is correct, would not result in an award being rendered in favor of the party that submitted such point. Pending its determination of the point, the tribunal may proceed with the rest of the arbitration, thereby

\begin{tabular}{ll}
\hline 8 & Ibid, art 27. \\
9 & Ibid, art 28. \\
10 & Ibid, art 29. \\
11 & Ibid, art 30. \\
12 & Ibid, art 23.1 and sch 4. \\
13 & Ibid, art 42. \\
14 & Ibid, art 43.
\end{tabular}


preventing any attempt to disrupt the whole arbitration by filing an abusive or belated EDP application.

- Third party funding: ${ }^{15}$ The 2018 Rules include express provisions to address the disclosure, confidentiality and costs of third party funding. These provisions respond to recent demands to regulate third party funding in arbitration in a manner that is in line with Hong Kong's recent legislative amendments to permit the use of third party funding in arbitration and associated proceedings in Hong Kong.

- Use of technology: the 2018 Rules identify the effective use of technology as a factor to be considered by an arbitral tribunal when determining appropriate procedures. ${ }^{16}$ The Rules also recognize the use of a secured online repository as an option for delivering and storing electronic documents. ${ }^{17}$

- Time limits for delivering awards: ${ }^{18}$ An arbitral tribunal is required to notify all parties and HKIAC of the anticipated date of delivering an award after the arbitral proceedings are declared closed. Such date must be within three months from the closure of the proceedings, unless all parties agree or HKIAC determines otherwise.

In addition to procedural rules, HKIAC has actively introduced new practice through the launch of practice notes, guidelines, model clauses and additional support services.

HKIAC plays a pioneering role in developing best practice on the use of tribunal secretaries in arbitration. In June 2014, H KIAC launched a tribunal secretary service together with a set of guidelines on the use of tribunal secretaries. This service allows an arbitral tribunal to appoint one of HKIAC's legal staff as its secretary to undertake administrative and organizational tasks at a much lower hourly rate. The service has proven to be a useful tool to save parties' costs and has met with growing demand. Since 2014, HKIAC legal staff have received 22 appointments. The quality of the service has been widely endorsed by international arbitrators. ${ }^{19}$

Another well-known practice introduced by HKIAC is the inclusion of a choice-of-law provision in its model clause to govern the arbitration agreement. ${ }^{20}$ In August 2014, HKIAC reviewed the relevant case law in Hong Kong, England, India, Singapore and Mainland China, and highlighted the

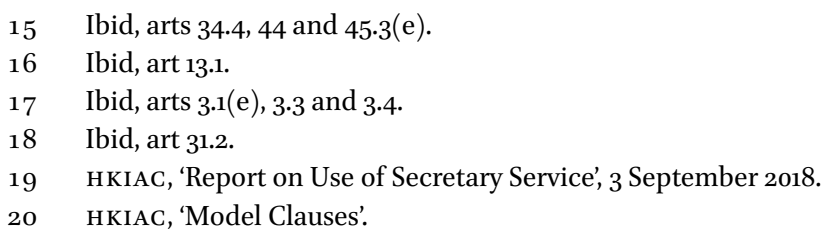


importance of including an express choice of law to govern the arbitration agreement, in the absence of which uncertainty might arise as to whether the arbitration agreement would be governed by the law of the underlying agreement or the law of the seat. Following the introduction of the model clause, an increasing number of commercial parties have included the choice-of-law provision in their contracts. ${ }^{21}$

HKIAC often introduces rules and practice following a comprehensive review of international practice, the approaches adopted by other arbitral institutions and users' feedback. HKIAC takes steps to update its practice on a regular basis and ensures that arbitral proceedings under HKIAC's auspices are conducted according to the highest standards.

\subsection{Participation in Legislative Reforms}

HKIAC's efforts in promoting best arbitration practice go beyond the proclamation of institutional rules and initiatives. The Centre has been involved in numerous law reforms to consider and recommend amendments to arbitration legislation in and outside of Hong Kong.

Over the past years, HKIAC has worked closely with the Department of Justice of Hong Kong (DoJ) to consider multiple key amendments to the Arbitration Ordinance. These include:

- Amendments to recognize expressly the appointment of emergency arbitrators and the enforceability of any emergency relief granted by an emergency arbitrator in or outside of Hong Kong. ${ }^{22}$

- Amendments to clarify that disputes over all aspects of an intellectual property (IP) right may be submitted to arbitration in Hong Kong and that it would not be contrary to the public policy of Hong Kong to enforce arbitral awards involving an IP right. ${ }^{23}$

- Amendments to permit the use of third party funding of arbitration and associated proceedings in Hong Kong and of costs of services provided in Hong Kong for arbitrations seated outside of Hong Kong. ${ }^{24}$

Before the above amendments came into force, HKIAC provided detailed submissions and analysis on the relevant legal issues and participated in subsequent discussions with representatives of DoJ. HKIAC also worked with

\footnotetext{
21 HKIAC, 'Choice of Law Provisions', 1 August 2014.

22 Hong Kong Arbitration Ordinance, ss 22A and 22B.

23 Ibid, ss 103A-103I.

24 Ibid, pt 10A (fully effective as of 1 February 2019).
} 
DoJ to ensure that the HKIAC Rules are compatible with the Arbitration Ordinance (for example, the provisions on third party funding and confidentiality) and that the Ordinance recognizes certain new provisions of the HKIAC Rules (for example, the emergency arbitrator procedure). In addition to amendments to the Arbitration Ordinance, H KIAC has also been involved in ongoing discussions regarding future arrangements on certain aspects of judicial assistance and cooperation between Hong Kong and Mainland China.

HKIAC has also made positive contributions to arbitration law reforms outside of Hong Kong. Through its Shanghai office, HKIAC maintains regular contacts with the arbitration community and relevant authorities in Mainland China and has taken active steps to facilitate arbitration reforms on the Mainland. The establishment of the Shanghai office in November 2015 was considered as a milestone development in Mainland arbitration, as HKIAC was the first offshore arbitral institution to open an office in Mainland China, paving the way for other international arbitral institutions to establish a similar presence on the Mainland. HKIAC visits the Supreme People's Court of China (SPC) on a regular basis. During these visits, HKIAC provides feedback to the SPC on the enforcement of foreign awards by the lower Chinese courts and discusses ways to improve the enforcement regime in Mainland China.

In recent years, representatives of HKIAC have also contributed to the arbitration reforms in Myanmar and Mongolia, providing advice to the local government on the enactment of its new arbitration act.

\subsection{Outreach Program and Events}

HKIAC runs an extensive outreach program connecting the Centre with international organizations, governments, courts, corporations, law firms, universities, chambers of commerce, professional associations and other interest groups around the world. Through its global network, HKIAC organizes or participates in various types of events in and outside of Hong Kong to promote effective means for resolving international disputes and to facilitate communications between international experts and local stakeholders on international dispute resolution.

Some of the most successful and effective program and events organized by HKIAC include the following:

- One of HKIAC's pinnacle events is the Hong Kong Arbitration Week which has been running for seven consecutive years. It has become a must-attend event for arbitration practitioners and attracts hundreds of participants every year to discuss the latest trends and issues in international dispute resolution. 
- HKIAC is the first arbitral institution to provide a tribunal secretary training program with the objectives of training young lawyers to become qualified tribunal secretaries. ${ }^{25}$ The program is taught by an experienced faculty who provides training through presentations, scenario analysis, legal drafting and group discussions. The program has been successfully held in Hong Kong, Singapore, Beijing, Shanghai, London, New York and Manila.

- HKIAC runs two regular workshops targeting in-house counsel, namely the Arbitration Clause Negotiation Workshop and the Pre-Arbitration Strategy Workshop. The Arbitration Clause Negotiation Workshop presents a realtime mock negotiation of arbitration agreements between two companies based on a case scenario. The Pre-Arbitration Strategy Workshop provides practical training on how a company should prepare for a dispute before the commencement of an arbitration with advice from international and local counsel, a third party funder and an asset recovery expert. Both workshops have been held in multiple cities across Asia, Europe and North America.

- HKIAC often partners with other organizations (such as UNCITRAL) to organize judicial training for judges in the Asia-Pacific region. Through the training, arbitration specialist and judges can have a direct and in-depth dialogue on international practice on the enforcement of arbitral awards and judicial support for arbitration.

- HKIAC organizes high-profile summits to connect legal and business communities in Hong Kong and an emerging economy. In May 2017, the Russia-Hong Kong Business and Legal Summit took place at HKIAC bringing together thought leaders from governments, corporations and law firms to discuss business opportunities and related legal issues faced by the relevant sectors in Russia and Asia. In May 2019, HKIAC will organize a similar summit focusing on investment in Africa.

- HKIAC has spearheaded Hong Kong's bid to host the International Council for Commercial Arbitration (ICCA) Congress on three occasions. The ICCA Congress, held biennially, is the largest regular conference dedicated to international arbitration and is renowned for its significant contribution to international dispute resolution. In April 2018, HKIAC and the Hong Kong government successfully persuaded the ICCA Governing Board to choose Hong Kong to host the ICCA Congress in 2022.

\section{$4 \quad$ Recent Statistics and Trends}

HKIAC maintains one of the largest caseloads in the Asia-Pacific region and has significant experience in international commercial disputes involving

25 HKIAC, 'Tribunal Secretary Training Program'. 
corporations and other commercial entities. In recent years, HKIAC has emerged as a preferred institution for the administration of investment treaty disputes and other disputes involving government entities or international organizations.

\section{1 $\quad$ Statistics and Trends}

Since its establishment, over 10,00o disputes have been submitted to H KIAC. In recent years, HKIAC maintains an annual caseload of around 500 disputes, out of which typically 250 to 300 disputes are arbitration matters. ${ }^{26}$

In 2018, HKIAC registered a total of 521 new cases. Of those cases, 265 were arbitrations, 21 were mediations and 235 were domain named disputes. $71.7 \%$ of all arbitration cases submitted to HKIAC in 2018 were international arbitrations. 39.4\% involved no Hong Kong parties and 8.4\% involved no Asian parties.

The total amount in dispute in all arbitrations submitted to HKIAC in 2018 was HK $\$ 49$ billion (US\$6.4 billion), which represented a $28 \%$ increase from US $\$ 5$ billion in 2017. The total amount in dispute in all arbitrations administered by HKIAC was HK $\$ 46.7$ billion (US $\$ 6$ billion). The average amount in dispute in administered arbitrations was $\mathrm{HK} \$ 320.1$ million (US\$41 million).

In 2018, disputes submitted to HKIAC arose from a wide range of sectors. The top five sectors were $(1)$ international trade $(29.6 \%),(2)$ corporate $(18.6 \%)$, (3) maritime (15\%), (4) construction $(13.7 \%)$, and (5) banking and financial services (11.9\%).

95\% of the HKIAC arbitrations commenced in 2018 were seated in Hong Kong. The remaining arbitrations were seated in Singapore, Seoul, Macao, and 'Hong Kong and India'.

The disputes submitted to HKIAC in 2018 were governed by 18 governing laws, with Hong Kong law as the most commonly chosen governing law, followed by English law and Chinese law.

$74 \%$ of the HKIAC-administered arbitrations commenced in 2018 were conducted in English. 13.7\% were conducted in Chinese and 8.2\% were in both Chinese and English. The remaining cases were conducted in both Japanese and English or both Korean and English.

Parties from 40 jurisdictions participated in the arbitrations commenced with HKIAC in 2018. The top five geographical origins of those parties were (1) Hong Kong, (2) Mainland China, (3) the British Virgin Islands, (4) the United States, and (5) the Cayman Islands.

Since 2011, HKIAC has registered 17 arbitrations involving government entities. Two of those arbitrations are investment treaty disputes between an 
investor and the host government. HKIAC is currently administering these arbitrations under the UNCITRAL Rules. One of the arbitrations is seated in Hong Kong and the other is seated outside of Hong Kong. The remaining 15 arbitrations are contractual disputes concerning construction projects, nonpayment of professional fees and non-provision of land.

It is anticipated that more investor-State disputes will be submitted to HKIAC in the coming years, as the Centre's Mediation Council has recently been designated as a mediation institution to administer disputes between a Mainland Chinese investor and the Government of Hong Kong pursuant to the Investment Agreement under the Mainland and Hong Kong Closer Economic Partnership Arrangement (CEPA). ${ }^{27}$

To date, HKIAC has administered two arbitrations involving international organizations. Further details of these arbitrations will be discussed in section 4.2 below.

The following trends can be identified from HKIAC's recent statistics:

- A growing number of high-value disputes are being referred to HKIAC. The total amount in dispute in HKIAC's arbitration matters increased from US $\$ 5$ billion in 2017 to US\$6.4 in 2018. The average amount in dispute in HKIACadministered arbitrations increased from US\$30.6 million in 2017 to US $\$ 41$ million in 2018. In our view, this trend is possibly driven by HKIAC's growing reputation as well as Mainland Chinese and other Asian companies' increasing bargaining power to secure an Asian venue for high-value disputes.

- The majority of arbitrations submitted to HKIAC continue to be cases administered by HKIAC under the HKIAC Rules or UNCITRAL Rules. In 2017, 156 out of 297 arbitrations (52.5\%) were administered by HKIAC under those rules. In 2018, 146 out of 265 arbitrations (55.1\%) were administered by HKIAC under those rules.

- Mainland Chinese parties remain the top overseas users of HKIAC arbitration. In 2017, HKIAC registered 103 arbitrations involving a total of 167 Mainland Chinese parties. In 2018, H KIAC registered 92 arbitrations involving a total of 128 Mainland Chinese parties.

- The majority of disputes submitted to HKIAC continue to arise from the international trade, corporate, construction and maritime sectors. In 2017, the top four sectors were international trade $(31.9 \%)$ construction $(19.2 \%)$, corporate $(13.5 \%)$ and maritime (8.8\%). In 2018 , the top four sectors were international trade $(29.6 \%)$, corporate $(18.6 \%)$, maritime $(15 \%)$ and construction $(13.7 \%)$. 
- HKIAC begins to administer investment treaty disputes with two investorState disputes being submitted to HKIAC in 2018.

\subsection{Use of HKIAC for Disputes Involving International Organizations}

HKIAC has growing experience in disputes involving international organizations and has recently been considered by several international organizations for inclusion in their arbitration agreements.

At the time of writing, HKIAC has administered two arbitrations involving an international organization. Both arbitrations were commenced by the same organization pursuant to the 1976 UNCITRAL Rules against different entities under different contracts.

In the first case, the organization agreed to lend US\$25 million to a borrower, to be repaid in instalments, under a Loan Agreement. The borrower paid the first eight instalments but failed to pay the remaining sums in the amount of US\$8.4 million. The organization contended that the borrower's failure to pay the remaining sums constituted an Event of Default under the Loan Agreement and therefore sought payment of the outstanding sums plus interest, financial charges and other costs in the arbitration. At the organization's request, the arbitration was suspended for the parties' settlement discussions shortly after the appointment of a sole arbitrator. It later unfolded that the parties entered into various payment agreements and the borrower allegedly failed to pay the amount in full within the prescribed time limit. The organization then sought to resume the arbitration and requested the tribunal to make an award based on the documents provided in the arbitration. In response, the borrower sought to further stay the arbitration. The arbitrator decided to continue the arbitration which is ongoing.

In the second case, the organization entered into a Shareholders Agreement and a Share Retention Agreement with three entities under which the organization held $20 \%$ shares in a Hong Kong entity. In the arbitration, the organization sought an order for specific performance of the Shareholders Agreement, a determination of losses and damages suffered by the organization and declaratory relief in respect of a series of actions allegedly taken by the three respondents which had the effect of diluting or decreasing the Hong Kong entity's shareholding in two companies. The parties subsequently reached a settlement and terminated the arbitration.

A number of international organizations have recently considered the inclusion of an HKIAC clause in some of their contracts.

A trust fund of a multilateral development bank has recently decided to include an HKIAC multi-tiered clause in their template Letter of Appointment for employment disputes between the trust fund and its employees. The clause 
refers any disputes to mediation before one mediator under the HKIAC Mediation Rules in the first instance. The clause further provides that, if the dispute is not settled within 30 days from the appointment of the mediator or within such period of time the parties may otherwise agree, it shall be submitted to arbitration seated in Hong Kong administered by HKIAC under the HKIAC Administered Arbitration Rules. The clause also includes specific qualifications of a mediator and an arbitrator and an undertaking that the trust fund bear costs unless it finds it unfair to do so.

The Asian Infrastructure Investment Bank (АІІB) has also recently announced that HKIAC, along with several other major institutions, is being considered for inclusion in AIIB's sample arbitration clauses for its private sector investment operations.

\section{$5 \quad$ Use of H KIAC for China-related Disputes}

HKIAC has long been the dispute resolution option of choice for disputes between Chinese and non-Chinese parties. It is attractive for Chinese parties who seek geographical proximity and cultural familiarity and for non-Chinese parties who seek a neutral and independent institution that applies international best practice.

HKIAC benefits from Hong Kong's role as a leading centre for international dispute resolution. With Hong Kong's status as the go-to place for transactions and disputes arising out of Chinese outbound investment, HKIAC is ready to tap the opportunities generated by the BRI and set to become the BRI dispute resolution hub.

BRI is an extensive outbound investment and development strategy launched by the Chinese government in 2013 to promote economic cooperation among countries along the BRI routes. ${ }^{28}$ BRI currently covers over 65 economies across three continents, about $60 \%$ of the world's population and one third of the world's GDP. ${ }^{29}$ With President Donald Trump's order withdrawing the US from the Trans-Pacific Partnership (TPP) in January 2017, BRI has the potential to become the world's largest network for regional collaboration. ${ }^{30}$

BRI is likely to generate a wide range of commercial and investment disputes in the infrastructure, transportation, logistics, maritime, energy and

28 HKIAC, 'Belt and Road Initiative'.

29 Ibid.

$30 \quad$ Grimmer and Liu 2017. 
financing sectors, between Chinese investors and their local partners or host governments in the BRI region. BRI projects tend to be cross-border, highvalue, capital intensive, long-term, multi-party and multi-contract, and involve public interest, different legal, political and economic systems. HKIAC is well placed to handle contract and treaty-based disputes arising from those projects for the following reasons:

- Experience: HKIAC has administered more disputes involving Chinese parties than any other non-Mainland arbitral institutions. In 2018, 34.7\% of arbitrations submitted to HKIAC involved a Mainland Chinese party, with Chinese state-owned entities consistently featuring in HKIAC's caseload. HKIAC also has extensive experience administering arbitrations involving parties from BRI jurisdictions. One third of the cases HKIAC handled in 2017 involved a Mainland Chinese party and a party from a BRI jurisdiction. HKIAC regularly handles cases of the type that will arise out of BRI projects, such as corporate finance, construction and maritime disputes.

- Enforceability: HKIAC awards made in Hong Kong are enforceable in nearly 160 jurisdictions globally under the New York Convention. Over $80 \%$ of BRI jurisdictions have ratified the New York Convention. HKIAC awards have an unrivalled record of enforcement in Mainland China. Since 2010, only three HKIAC awards were not enforced by the Chinese courts.

- Affordability: Most of the BRI countries are emerging economies and the HKIAC Rules offer multiple mechanisms to controls costs. For example, parties can choose the most cost-saving way to pay their arbitrators between hourly rate and ad valorem systems. As HKIAC adopts a light touch approach to case administration, its administrative fees are generally lower than the fees charged by other major arbitral institutions. HKIAC also offers its premium hearing space for disputes involving a developing State listed on the OECD development assistance list. $70 \%$ of the BRI jurisdictions are on that list.

- Efficiency: The HKIAC Rules can be strategically used to control costs and increase efficiency in multi-party and multi-contract disputes, of the kind that typically arise in construction, joint venture and project finance disputes. The Rules allow multiple arbitrations to be consolidated, additional parties to be joined to arbitrations, single arbitrations to be commenced under multiple contracts and the conduct of concurrent proceedings. There are also procedures to expedite proceedings, to determine meritless points of law or fact on a summary basis, and to appoint an emergency arbitrator to grant urgent relief before an arbitral tribunal is constituted.

- Neutrality: HKIAC is independent and free from any type of influence and control. All cases submitted to HKIAC are handled by a multi-national and 
multi-lingual Secretariat. HKIAC is headquartered in Hong Kong which upholds the rule of law and has an independent judiciary which has been consistently ranked first in Asia for judicial independence.

- Dedicated BRI initiatives: HKIAC has a dedicated BRI program including a BRI Advisory Committee and an online BRI Resource Centre. The BRI Advisory Committee includes 12 members with strong expertise across a broad range of BRI industry sectors. The online Resource Centre provides comprehensive information about BRI projects, dispute resolution options and related events.

\section{$6 \quad$ Conclusion}

Over the past years, HKIAC has become a key driving force for the development of international dispute resolution. The Centre has made considerable efforts in promoting and implementing effective methods of resolving international commercial and investment disputes through the introduction of institutional rules and practice, the facilitation of law reforms, and the implementation of an extensive outreach program connecting HKIAC and Hong Kong's legal and business community with numerous other jurisdictions. Recent statistics indicate that HKIAC is emerging as a preferred institution for high-value and complex disputes involving government entities or international organizations. H KIAC's administration of two ongoing investor-State arbitrations, its designation as a mediation institution for disputes between a Mainland Chinese investor and the Hong Kong government under the CEPA Investment Agreement and the recent inclusion of HKIAC clauses in several multilateral development banks' template contacts reflect this trend.

With its extensive experience and proven record of handling China-related disputes, HKIAC anticipates playing a greater role in BRI disputes which may involve government entities from BRI jurisdictions and international organizations. HKIAC has the experience and offering required for resolving both commercial and investment disputes arising from BRI projects and is set to make further contributions to effective international dispute resolution in that context.

\section{Reference List}

Global Arbitration Review, 'Guide to Regional Arbitration (2018) vol 6: Whitelist / Institutions Worth a Closer Look-Asia/Asia Pacific' (Global Arbitration Review, 
17 November 2017) <https://globalarbitrationreview.com/insight/guide-to-regional -arbitration-volume-6-2018/1150109/whitelist-institutions-worth-a-closer-look -\%E2\%80\%93-asia-asia-pacific > accessed 22 January 2019.

Global Arbitration Review, 'Hearing Centre Surveys 2015-2019' (Global Arbitration Review, 2 January 2019) < https://globalarbitrationreview.com/editorial/1178420/survey -results $>$ accessed 29 January 2019.

Grimmer S and Liu J, 'HKIAC well-positioned as Belt \& Road dispute resolution hub' (Asialaw 2017) <www.asialaw.com/articles/hkiac-well-positioned-as-belt-and-roaddispute-resolution-hub/arszqdoy> accessed 11 February 2019.

HKIAC, 2018 HKIAC Administered Arbitration Rules (2018) <www.hkiac.org/arbitra tion/ rules-practice-notes/hkiac-administered-2018> accessed 12 February 2019.

HKIAC, 'HKIAC Adds Choice of Law Provisions to its Model Clause' (HKIAC, 1 August 2014) <www.hkiac.org/news/hkiac-adds-choice-law-provisions-its-model-clause> accessed 30 January 2019.

HKIAC, 'HKIAC-HKMC to Provide Mediation Services for Investment Disputes' (HKIAC, 16 January 2019), <http://hkiac.org/news/mediation-services-investment -disputes $>$ accessed 1 February 2019.

HKIAC, 'Model Clauses' (HKIAC) <www.hkiac.org/arbitration/model-clauses>, accessed 30 January 2019.

HKIAC, 'Overview of the Belt and Road Initiative' (HKIAC) < www.hkiac.org/Belt-andRoad/overview-belt-and-road-initiative $>$ accessed 11 February 2019.

HKIAC, 'Report on Use of HKIAC Tribunal Secretary Service' (HKIAC, 3 September 2018) <http://hkiac.org/node/2299> accessed 30 January 2019.

HKIAC, 'Rules \& Practice Notes' (HKIAC) < www.hkiac.org/arbitration/rules-practicenotes $>$ accessed 29 January 2019.

HKIAC, 'Statistics' (HKIAC) <www.hkiac.org/about-us/statistics> accessed 11 February 2019 .

HKIAC, 'Tribunal Secretary Training Programme' (HKIAC) <http://hkiac.org/ arbitration/tribunal-secretaries/tribunal-secretary-training-programme $>$ accessed 30 January 2019.

HKLII, 'Hong Kong Arbitration Ordinance Cap 6og' (HKLII) <www.hklii.hk/eng/hk/ legis/ord/6og/> accessed 12 February 2019.

Queen Mary University of London and White \& Case LLP, '2018 International Arbitration Survey: The Evolution of International Arbitration' (White \& Case LLP 2018) < www.arbitration.qmul.ac.uk/media/arbitration/docs/2018-InternationalArbitration-Survey-report.pdf $>$ accessed 22 January 2019.

UNCITRAL, UNCITRAL Arbitration Rules (1976, 2010, 2013) <www.uncitral.org/ uncitral/en/uncitral_texts/arbitration/2010Arbitration_rules.html > accessed 11 February 2019. 